\title{
PAST AND PRESENT OF CHAGAS DISEASE IN NORTHERN CHILE*
}

\author{
PASADO Y PRESENTE DE LA ENFERMEDAD DE CHAGAS \\ EN EL NORTE DE CHILE
}

\author{
Aldo Solari ${ }^{1}$
}

\begin{abstract}
Contemporary understandings of the epidemiology of Chagas disease as well as it's clinical features, together with knowledge of the insect vectors and genotypes of the causal agent Trypanosoma cruzi are important pieces of information for comparisons with cases in the past. Evidence indicates that 4,000 years ago in northern Chile cases displaying digestive symptoms or 'megacolon' were frequent. Recent information on the dispersion of the domestic insect vector Triatoma infestans allows us to conclude that in the past only the wild Mepraia gajardoi insect vector transmitted Trypanosoma cruzi in its native area. This information together with current knowledge about Trypanosoma cruzi circulating in the area and transmitted by Mepraia gajardoi will be important to establish possible host-parasite association with Chagas disease pathology.
\end{abstract}

Key words: Chagas, T. cruzi genotypes, insect vectors.

El conocimiento de la epidemiología de la enfermedad de Chagas en el norte de Chile en nuestros días tales como las características clínicas, los insectos vectores del parásito hasta los genotipos del agente causal Trypanosoma cruzi son importantes para contrastar la situación con el pasado. La evidencia nos indica que hace 4.000 años en esta zona endémica hubo casos clínicos frecuentes con síntomas digestivos de la enfermedad de Chagas o megacolon. Los datos recientes sobre dispersión del insecto vector doméstico Triatoma infestans permiten concluir que en el pasado sólo el vector nativo y silvestre Mepraia gajardoi transmitía Trypanosoma cruzi. Esa información y el conocimiento actual de los genotipos de T. cruzi circulando en el área y transmitidos por M. gajardoi serán importantes para establecer posibles asociaciones huésped-parásito con la patología de la enfermedad de Chagas.

Palabras claves: Chagas, genotipos T. cruzi, insectos vectores.

Chagas disease or American trypanosomiasis is an old and wide-spread zoonosis from United States to the Southern Argentina caused by the protozoon parasite Trypanosoma cruzi. The theory about the natural history of Chagas disease proposes that humans were included in the T. cruzi transmission cycle as a consequence of acquisition of sedentary habits and as a consequence of colonization by triatomine vectors of human dwelling. It is thought that the insect vector adaptation (Triatoma infestans) to human dwellings occurred in early agroceramic cultures of Argentina 500 AD., as well as in Southern Perú and easter Bolivia (Dujardin et al. 1998; Noireau et al. 2009). This fact and the ancient practice of Andean ethnics to raise guinea pigs for consumption could have favored insect vectors to colonize cultures human habitats and the zoonosis (Rothhammer et al. 1985). Chile is an interesting country to study Chagas disease since evidence has been found in mummies revealing the presence of clinical manifestations of the disease and the confirmation of $T$. cruzi presence in several mummies tissues (Guhl et al. 1999; Rothhammer et al. 1985). The present review describe the origin of the etiologic agent and variants of T. cruzi, the insect vectors as invertebrate hosts that transmit the parasite, the participation of reservoir animals and clinical manifestations in infected humans in the past and present, with special emphasis in Northern Chile. The study of this parasite in antiquity allow us to understand health conditions of prehispanic populations and parasite host interactions related to subsistence patterns and cultural development achieved by ancient population. The richness of northern Chile bioarchaeological record, as well as the developmental conditions permits us to determine the presence of this parasite in antiquity.

* Este artículo fue presentado en el Taller de Bioarqueología "Avances y Desafíos del Paleoambiente y la Paleoparasitología", Arica, noviembre 2008. De 15 ponencias expuestas 7 fueron seleccionadas para ser evaluadas por investigadores externos. Luego fueron editadas por Bernardo Arriaza y Nancy Orellana, en su calidad de editores invitados de la Revista.

1 Program of Cellular and Molecular Biology. ICBM. Facultad de Medicina, Universidad de Chile. Casilla 70086, Santiago 7, Chile.asolari@med.uchile.cl 


\section{T. cruzi Transmission and Clinical Aspects of Chagas Disease}

The parasite $T$. cruzi moves among mammals, humans and triatomines insects during its life cycle. A triatomine picks up the parasitic infection by feeding on the blood of an infected animal or human. Once inside, the parasite divides rapidly in the insect gut before emerging in its feces. When the triatomine takes another blood meal, it defecates on the skin of the victim, depositing T. cruzi in the process. The parasite is able to penetrate the new host if the skin is broken by the bug or through other cuts and abrasion, or through the soft skin of the eyes and month. It can infect the cells of the soft tissues below, and them enter the blood stream and circulate to reach other body tissues where they divides and finally after host cell destruction they reach the blood stream amplified.

T. cruzi can be transmitted by several ways, being the most efficient via faecal deposits from infected vectors, but other routes as blood transfussion from infected donors, transplacental transmission from infected mothers, and oral transmission by eating infected material. The oral route transmission would seem to be the primitive state. Small mammals transmission would seem most likely to occur when they eat infected insects (Aufderheide et al. 2005). Therefore this route in more probable than the vectorial one in wild mammals since the parasite must pass though the dense fur of the animal.

These $T$. cruzi proliferate and generate tissue damage, reaching a high parasitemia after colonized cells destruction, triggering a strong immune response of the host (acute phase). Later on the parasite colonize other tissues and evade the immune response until subpatent parasitemia are observed. The infected host can evolve to the chronic phase after up to 30 years, and develop clinical characteristic symptoms of Chagas disease. It is accepted that approximate $30 \%$ of the infected subjects develop some clinical symptom, the other $70 \%$ remains asymptomatic and can present some abnormal electrocardiographic tracks. It is thought that in Chile the most characteristic symptom is the cardiac one (Arribada et al. 1990). However, others propose that digestive alterations such as dolico/ megacolon is the most frequent (Calderón 1992). The esophagous alterations some as in other countries are the less frequent but a study with few cases revealed incomplete sphincteric relaxation, which is the most typical manometic finding in Achalasia (Csendes et al. 1975).

\section{Chagas Disease in Northern Chile}

One study conducted in the XV geographical region of Chile revealed an average prevalence of $10.5 \%$ being much less in rural areas of Arica than Iquique with figures of $7 \%$ and $13 \%$, respectively (Arribada et al. 1993). Other epidemiologic studies revealed that human infection is between 12.5$14.4 \%$ in the whole region (Apt and Reyes 1986; Knierim and Saavedra 1966; Martínez et al. 1983; Villarroel et al. 1991). It is worth to point out that major detection among pregnant women was found in Arica than Iquique, with figures of $1.7 \%$ and $0.7 \%$, respectively (Apt and Reyes 1986). One of these studies demonstrated that Chagas disease is more prevalent in localities far away from the coast. Prevalence in human subjects between 0-1500 m (coastal settlement), was three times less than in those living between 1500-3000 m (intermediate settlement) with figures of $7.5 \%$ and $22.7 \%$, respectively (Villarroel et al. 1991). This study also revealed that electrocardiographic alterations of Chagas disease were five times more frequent than non infected subjects. However those infected subjects over 3,000 m presented more electrocardiographic abnormalities typical of Chagas disease such as bifascicular blocks and conduction alterations (Arribada et al. 1993), than those living in the intermediate and coastal stettlements with $14.3 \%, 6.2 \%$, and $4.4 \%$, respectively (Villarroel et al. 1991). These figures are compared at that date with a national average of $6.8 \%$ and demonstrate that altitude is a major factor to consider in Chagas disease epidemiology (Villarroel et al. 1991). Besides the high level of electrocardiographic alterations detected among infected and non infected persons, the number of symptomatic cases was low, which do not indicate absence of myocardial damage in asymptomatic cases (Arribada et al. 1990). Even though there are several studies of Chagas disease, the methods to study digestive alterations are complex and require equipments only available in hospitals. One of the few complete clinical studies was conducted with asymptomatic chagasic patients. This study performed among blood donors and mostly from persons of the IV region revealed interesting results. The study showed that dolico/megacolon was more prevalent 
(30.2\%), than myocardial damage measured by electrocardiographical abnormalities (23\%), and dilated aesophagus (14\%). Another interesting conclusion was that Chagas disease can present multiple organic involvements in $12 \%$ of the cases, and these cases seems not to demand longer times of evolution (Calderón 1992).

As a whole chagasic studies with electrocardiographic tracks revealed discordant results among several groups however digestive alterations and specially megacolon is characteristic of Chagas disease (Atias 1980). This author determined that 9 out of 10 cases of megacolon in Chile are of chagasic aetiology, and that $23.9 \%$ among asymptomatics and $45 \%$ of symptomatics have dolico/megacolon (Calderón and Aldana 1987). It is worth to point out that the most characteristic symptoms of these patients are the different degrees of constipation and further complications as fecaloma.

\section{Antiquity and Diversity of the Trypanosoma cruzi Taxon}

All trypanosomes are parasites and the present thought is that they have a monophyletic origin. The suggestions is that the original parasitic forms developed prior to splitting up the continents during the mesozoic era, approximately 230 mya. Meantime development of the cruzi clade is thus suggested to have initiated prior to splitting up the southern continent Gondwanaland in the cenozoic era (Briones et al. 1999).

The earliest forms of cruzi are deduced to have been associated with marsupial opossums at the time of separations of South America from Gondwana about 40 mya. T. cruzi is diploid but asexualy reproduced. This observation was early stablished since population genetic studies with mitochondrial markers and nuclear loci coding for isoenzymes highly correlated. This association strongly supported a clonal propagation of the parasite (Tibayrenc and Ayala 1987).

Two major lineages exist of T. cruzi, known as TcI and TcII. Subdivision of TcII exist (TcIIa, b, c, $\mathrm{d}$ and e) as described (Westenberger et al. 2005). However a new consensus nomenclature exist for the six discrete typing units from TcI to TcVI (Zingales et al. 2009). Genetic diversification among $T$. cruzi lineages was performed by the statistic D "genetic distance" (Nei 1972), which estimates the number of allelic substitutions at the nuclear DNA that have occurred in two organism since they last shared a common antecetor. When two different $T$. cruzi genotypes of TcI and TcII are compared at the level of multi locus enzyme electrophoresis, genetic distances differ over 2.0, which implies the taxon $T$. cruzi as genetically extremely heterogeneous, a $\mathrm{D}$ value that spread over a range that covers the level of genetic divergence between different subspecies, and genera in animals. For example the $\mathrm{D}$ value for comparisons between the orangutan and either humans or the other great apes is approximately 0.6 . The divergence of these species occurred some 15 mya. If we assume as a rough approximation similar rates of evolution in T. cruzi and in the antropoids, it is possible to conclude that TcI and TcII diverged more than 50 mya (Ayala 1993). However all these are rough stimation for sexually reproduced organisms. T. cruzi is asexualy reproduced, therefore these figures should be higher in a slower molecular evolution as for a clonal propagation organism.

Epidemiological studies based on T. cruzi isolates from different host origins make people suggest that $\mathrm{TcII}$ is associated with placental mammals and TcI with marsupials. However in South America the prevalence of TcII seems to be independent of host type, marsupial or placental (Briones et al. 1999). TcII is composed of several sublineages, some of them generated for hybridization events or asexualy recombinant processes from the oldest $T$. cruzi lineages (TcI and TcIIb) (Westenberger et al. 2005). The evolutionary history of $T$. cruzi has been determined, recently and the modern hybrids TcIId and TcIIe are associated with digestive symptoms of Chagas disease, meantime TcI are with cardiac lesions (Rozas et al. 2008).

Few studies have been performed with T. cruzi genotypes circulating in northern Chile. These studies were conducted on $T$. cruzi isolates from patients and the domiciliary insect vector with complex methods. These studies revealed that $T$. cruzi genotypes TcI, TcIId and TcIle were found circulating in this endemic area (Arribada et al. 1990; Venegas et al. 1997; Solari et al. 1998). Interestingly molecular karyotyping evidence two variants of TcI, with very low genetic distances among them $\mathrm{D}=0.017-0.04$ (Ayala 1993). More recently using cytocrome b gene sequencing it is possible to differentiate these two TcI genotypes as very different organisms with an estimation split of 27 mya among them (Spotorno et al. 2008). 
Only TcIId was found in human derived T. cruzi isolates, meantime TcI and TcIIe were found in the domestic T. infestans insect vector isolates (Arribada et al. 1990). Something similar was observed for T. cruzi isolates from humans and T. infestans of San Pedro de Atacama in the II region (Gonzalez et al. 1995).

More recently the selvatic insect vector Mepraia gajardoi was studied in Northern Chile and it was found infected with T. cruzi in the coasts of Arica and Medano (II region) where at least the T. cruzi genotype TcIlb was found (Botto-Mahan et al. 2008; Carvajal et al. 2007). Future studies of this selvatic vector M. gajardoi and the T. cruzi genotypes transmited are necessary to evaluate the human risk of infection in this regions with $T$. cruzi as well in the past. It is thought that fishermen and algae harvesters living in rocky habitats of this geographic area can be infected this way by their proximity with $M$. gajardoi.

\section{Triatominae Vectors in the Andean Region}

The triatominae are insects vectors of the Reduviidae family (Hemiptera) that feed and suck blood from vertebrates, therefore they transmit T. cruzi to humans. They are an ancient family that presumably have derived from phytophagous Hemiptera some 230 mya (Evans 1956). Predatory reduviids have at present a worldwide distribution with at least 6,000 species. All reduviid subfamilies at present seem to be represented in America and at least three subfamilies of predatory reduviid are represented in amber 25-65 mya from Mexico and the Caribbean (Schofield 2000).

It is thought that the blood-sucking Triatominae are generally poorly differentiated from predatory reduviids, both in body shape and habitat, all suggestive that they have evolved to the blood-sucking habit relatively recently (Schofield 2000). Within Triatominae there is evidence for rapid evolutionary changes, to mention, comparison of derived populations of T. cruzi insect vectors in Central America, with their putative populations in Colombia and Venezuela, shows them to be morphologically different and with reduced genome. Another example is the comparison of domestic T. infestans from Uruguay and other South American countries, with their original selvatic populations in Bolivia, again shows clear morphometic and genetic differentiation over a short time scale no more than 100 years (Dujardin et al. 1998).
T. infestans is recognized as the most important insect vector species in South America, and responsable for about the half of 18 million people infected by T. cruzi (WHO 1991). It was distributed in Argentina, Bolivia, Brazil, Chile, Paraguay, Uruguay and Perú. Because of his exclusive domiciliary habitat the vector control programme launched in 1991 was successful and several areas of Uruguay, Chile and Argentina are already vector free. The T. infestans origin is thought to be the Andean Valleys of Cochabamba, Bolivia where this species is selvatic (Torrico 1946; Dujardin et al. 1987). However studies with genetic markers (isoenzyme genetic frequencies) revealed that the origin of T. infestans dispersion was from the Sucre, Potosí and especifially from Vallegrande in Cochabamba Bolivian regions (Dujardin et al. 1998). According to Dujardin (1998) the original and selvatic T. infestans of Bolivia was adapted 3500 years ago to a domestic habitat associated with human dwellings of pre inca cultures and the domestication of selvatic rodents as food source (Kyle 1987). Later on it was proposed that $T$. infestans recently dispersed to near localities by fly, but to great distances by means of passive transport with humans (Dujardin et al. 1998). Two geographically separated chromosomic groups of T. infestans have been identified. They are named Andean (Bolivia, Peru) and Non Andean (Argentina, Paraguay, Brazil, Uruguay and Bolivian Chaco). The Andean variant, presumably the ancestral one with $50 \%$ more heterochromatin, have a higher genome. It is thought that the Andean variant (adapted to high lands) is the one dispersed to Northern Chile, and the non Andean variant (adapted to low lands) in Argentina dispersed later to the III and central regions of Chile based on preliminary studies (Panzera et al. unpublished). Interestingly there is a natural geographic barrier between the II and III regions corresponding to the Atacama Desert which split the country in two separately endemic areas.

T. infestans studies (performed 1982-1983) in the North of Chile revealed an interesting distribution. Meantime T. infestans infestation was close to $25 \%$ in rural areas of Camarones (Arica), Huara, Camiña and Pica (Iquique), this figure was 0 and $0.6 \%$ Putre and Arica city, respectively (Martínez et al. 1983). As a whole $5.8 \%$ of T. infestans were infected. The higher infestation and infection rates in localities of Iquique compared to Arica also is observed on infection rates in domestic animals, where cats, sheeps and dogs were the most infected (Martínez 
et al. 1983). Other epidemiological studies in the North of Chile performed at different altitudes confirm the higher distribution of $T$. infestans in rural areas of Iquique (16\%) than Arica $(0.5 \%)$ up to $1,500 \mathrm{~m}$ (coastal settlement), and much higher 1,500-3,000 m (intermediate settlement) with figures of 25-35\%, respectively (Villarroel et al. 1991).

Meantime the participation of the domestic T. infestans vector is documented to explain T. cruzi human infection, the secondary, selvatic and native vector M. gajardoi of Chile is not clear what participation have in the epidemiology of Chagas disease in this region. Mepraia species are mainly found amongst rockpiles in the arid northern regions (Frias et al. 1998). Acording to these authors, M. gajardoi is distributed approximately between $18^{\circ} \mathrm{S}$ and $26^{\circ} \mathrm{S}$ and is the only genus of Triatominae showing marked wing polymorphism. Females are invariable wingless, while males are invariably winged (Frias et al. 1998). Biometric results of antennal phenotype in the genus Mepraia suggest that they could have a common ancestor and had begun their divergence when the Andean Range lifted 20 mya (Moreno et al. 2006). Recent studies have determined that M. gajardoi populations from the coast of Arica and Medano (II region) are infected with T. cruzi but at low rates, eventhough highly sensitive $T$. cruzi detection methods have been used (Botto-Mahan et al. 2008; Carvajal et al. 2007).

\section{Human occupation, Fauna and Vegetation of Northern Chile Since the Early Archaic}

The documented information about the palaeoindians in Southern America may have occurred as early as 14.600 years ago (Dillehay et al. 2008). Other palaeoindians of the central Atacama highland are described for that period (Núñez et al. 2002). However only during the early archaic $(11,000-8,000$ years) did small mobile bands of foragers begin to occupy the altiplano by moving seasonally from the upland valleys to the caves and rock skelters at higher altitude. Late Pleistocene exploration camps have been documented at lower elevations $(3,000 \mathrm{~m})$, whereas the high Andes ( $>4,000 \mathrm{~m})$ were not occupied until well into the Early Holocene (Moreno et al. 2009; Núñez et al. 2002). The extreme lack of precipitation is a feature that has remained stable over millions of years because of major coupled atmospheric and tectonic feedbacks. However short lived times of increased precipitations exist in paleohydrological records at elevations above 2,000 m, reflecting millennial-scale variations in global climate. Increased surface hydrologic flow over this region during predominantly Late Pleistoceno humid interval may have mofified the landscape, therefore fauna and flora. Although many of these geographic areas are plantless today, these terraces and fans literally abound with pleistocene fossil wood and leaf berds, all of which are found in situ or have been transported only very short distances. Vegetation in Northern Chile is primary limited by the amount of summer rainfall, which vary as a function of rainout with elevation and distance from the crest of the Andes. With the exception of occasional herbaceous lomas vegetation (fog-zone as band of vegetation) below 1,000 m, the Cordillera Occidental below 2,700 m consist of absolute desert where plants are absent from the landscape. Above 2,700 m exist the prepuna located in the Andean precordillera and consisting of widely spaced xerophylic plants characterized by several shrubs species, cactus, and the animal Calandrinea, Lepidium, and Cistanthe. Rodent middens are deposits of plant material (seeds, leaves, twigs, bones, pollen and fecal pellets) encased in crystalline urine, which are abundantly preserved in rock shelters, crevices, and caves of the Atacama Desert. Midden-forming rodents in northern Chile include Abracoma cinerea, Lagidium viscacia, and Phyllotis spp. The identification of $>40$ taxa of plant macrofossil in 14 rodent middens collected from 2,800 to $3,590 \mathrm{~m}$ at the latitude of Arica $\left(18^{\circ} \mathrm{S}\right)$ provided snapshots of vegetation in the northermost Atacama desert over the past 3000 years. However midden floras showed considerable stability, throughout the Late Holocene (Holmgren et al. 2008). All this information is relevant to determine the potential impact on Chagas disease in the wild transmission on cycle at that time.

\section{Chagas Disease in Mummies of Northern Chile}

In 1984 was published the outstanding paper of Rothhammer et al. 1984, and a second one (Rothhammer et al. 1985) describing for the first time evidence of Chagas disease in Pre-Columbian South America. They found clinical manifestations of Chagas disease (megasyndroms of colon, including fecaloma and cardiomegaly) in 9 mummies dated 1385-2455 years in Quebrada de Tarapacá 
at $1,500 \mathrm{~m}$, but not in mummies at $150 \mathrm{~km}$ north in the Azapa Valley. Later on these results were confirmed by the existance of this disease in 143 out of 283 mummified humans dated in a extensive period of 9,000-9,200 years along the coast of Southern Peru and II region of Chile (Aufderheide et al. 2004). This study determined by PCR amplification of $T$. cruzi DNA revealed a prevalence rate for Chagas'disease in the entire population of $40.6 \%$ with no significant difference among the different older cultural groups (Chinchorro, Acha and Alto Ramírez), and the more recent ones (Cabuza, Chiribaya, and Inca). Interestingly most of the bodies were recovered from low Valley sites within $25 \mathrm{~km}$ inland or from sandy beach sites, suggesting that $M$. gajardoi more than T. infestans was the insect vector propagating Chagas' disease in those areas. The Chinchorros were the earliest culture that inhabited this coastal zone and had a maritime subsistence. The subsequent succession of cultures after the Chinchorros was characterized by an increase of agriculture and camelid herding, originated in the Andean highlands probably living in adobe houses.

Other report in Northern Chile (San Pedro de Atacama) in the II region revealed four mummies dated 600-4,000 years and infected with T. cruzi and detected by means of PCR (Ferreira et al. 2000). This finding at an altitude of $2.436 \mathrm{~m}$ above sea level, without megavisceral lesions probably represent human cases infected by $T$. infestans which adapted to that habitat after dissemination from Bolivian highlands. However, and considering the late or recently dissemination of $T$. infestans to Northern Chile, the oldest infected mummies living in coastal settlement probably where infected by the indigenous insect vector M. gajardoi. New evidence of mummies infected with T. cruzi in Brazil emerge (Araújo et al. 2009; Lima et al. 2008). These authors besides to identify $T$. cruzi DNA sequences can genotype the infective T. cruzi, an aspect important to identify the parasite variants circulating in the past. In sum, our review suggest that $T$. cruzi infection with TcI, TcIId and TcIIe affected ancient Andean populations independently of ecological setting, time period and subsistence.

Acknowledgments: The secretarial assistance of Ms Ximena Coronado is greatly appreciated, FONDECYT 1085154 and Convenio de DesempeñoUTA-MINEDUC. The criticism of the journal referee's is also appreciated.

\section{References Cited}

\section{Apt, W., and H. Reyes}

1986 Aspectos epidemiológicos de la enfermedad de Chagas en Chile. I: Distribución geográfica, índices de infección en vectores y en humanos. Parasitología al Día 10:94-101.

Araújo, A., A.M. Jansen, K. Reinhard, and L.F. Ferreira

2009 Paleoparasitology of Chagas disease-A Review. Memórias do Instituto Oswaldo Cruz 104:9-16.

Arribada, A.C., W.B. Apt, .X. Aguilera, A. Solari, A.M. Arribada, and J.R. Sandoval

1990 Cardiopatía chagásica en la primera región de Chile. Estudio clínico, epidemiológico y parasitológico. Revista Médica de Chile 118:846-854.

Arribada, A.C., W. Apt, X. Aguilera, A Solari, J.M. Ugarte, J. Sandoval, and A. Arribada

1993 Cardiopatía chagásica en Chile. Cardiología Intercontinental 2:94-99.

Atias, A.

1980 Enfermedad de Chagas digestiva. Una experiencia de 20 años. Boletín Hospital San Juan de Dios 27:251-257.

Aufderheide, A.C., F. Salo, M. Madden, J. Streitz, J. Buikstra, F. Guhl, B. Arriaza, C. Renier, L.E. Wittmers Jr., G. Fornaciari, and M. Allison

2004 A 9,000-year record of Chagas' disease. Proceedings of the National Academy of Sciences of the USA 101:20342039.
Aufderheide, A.C., W. Salo, M. Madden, J. Streitz, K.D. de la Cruz, J. Buikstra, B. Arriaza, and L.E. Wittmers Jr.

2005 Aspects of ingestion transmission of Chagas' disease identified in mummies and their coprolites. Chungara Revista de Antropología Chilena 37:85-90.

Ayala, F.J.

1993 Trypanosoma and Leishmania have clonal population structures of epidemiological significance. Biological Research 26:47-63.

Botto-Mahan, C., M. Sepúlveda, M.Vidal, M. Acuña-Retamar, S. Ortiz, and A. Solari

2008 Trypanosoma cruzi infection in the sylvatic bug Mepraia gajardoi from the Chilean Southern Pacific Ocean coast. Acta Tropica 105:166-169.

Briones, M.R., R.P. Souto, B.S. Stolf, and B. Zingales 1999 The evolution of two Trypanosoma cruzi subgroups inferred from rRNA genes can be correlated with the interchange of American mammalian faunas in the Cenozoic and has implications to pathogenicity and host specificity. Molecular and Biochemical Parasitology 104:219-232.

Calderón, C., and M. Aldana

1987 Estudio del colon en pacientes chagásicos asintomáticos y sintomáticos. Parasitología al Día 11:65-71.

Calderón, C.M.

1992 Estudios digestivo y cardiológico simultáneos en pacientes chagásicos asintomáticos. Revista Médica de Chile 120:43-47. 
Carvajal, A., J. Orellana, W. Wigant, C. Bohórquez, and I. Lobato

2007 Prevalencia de triatominos infectados con Trypanosoma cruzi en litoral de la ciudad de Arica. Parasitología Latinoamericana 62:118-121.

Csendes, A., T. Strauszer, and P. Uribe

1975 Alterations in normal esophageal motility in patients with Chagas' disease. Digestive Disease 20:437-442.

Dillehay, T.D., C. Ramírez, M. Pino, MB. Collins, J. Rossen, and J.D. Pino-Navarro

2008 Monte Verde: Seaweed, food, medicine, and the peopling of South America. Science 320:784-786.

Dujardin, J.P., M. Tibayrenc, E. Venegas, L. Maldonado, P. Desjeux, and F.J. Ayala

1987 Isoenzyme evidence of lack of speciation between wild and domestic Triatoma infestans (Heteroptera: Reduviidae) in Bolivia. Journal of Medical Entomology 24:40-45.

Dujardin, J.P., C.J. Schofield, and M.Tibayrenc

1998 Population structure of Andean Triatoma infestans: Allozyme frequencies and their epidemiological relevance. Medical and Veterinary Entomology 12:20-29.

Evans, J.W.

1956 Palaeozoic and Mesozoic Hemiptera (Insecta). Australian Journal Zoology 4:165-258.

Ferreira, L.F., C.Britto, M.A. Cardoso, O. Fernandes, K. Reinhard, and A. Araújo

2000 Paleoparasitology of Chagas' disease revealed by infected tissues from Chilean mummies. Acta Tropica 75:79-84.

Frias, D., and J. Atria

1998 Chromosomal variation, macroevolution and possible parapatric speciation in Mepraia spinolai (Porter) (Hemiptera: Reduviidae). Genetic and Molecular Biology 21:179-184.

González, J., S. Muñoz, S. Ortiz, D. Anacona, S. Salgado, M. Galleguillos, I. Neira, H. Sagua, and A. Solari

1995 Biochemical, Immunological and Parasitological characterization of Trypanosoma cruzi populations on the Andean North of Chile. Experimental Parasitology 81:125-135.

Guhl, F., C. Jaramillo, G.A. Vallejo, R. Yockteng, F. CárdenasArroyo, G. Fornaciari, B. Arriaza, and A.C. Aufderheide 1999 Isolation of Trypanosoma cruzi DNA in 4,000-Year-Old Mummified Human Tissue from Northern Chile. American Journal of Physical Anthropology 108:401-407.

Holmgren, C.A., E. Rosello, C. Latorre, and J.L. Betancourt 2008 Late-Holocene fossil rodent middens from the Arica region of northernmost Chile. Journal of Arid Environments 72:677-686.

Kyle, R.

1987 Rodents under the carving knife. New Scientif 1566:5862.

Knierim, F., and P. Saavedra

1966 Técnica de la reacción de la hemaglutinación aplicada al diagnóstico serológico de las parasitosis. Boletín Chileno de Parasitología 21:39-44.

Lima, V.S., A.M. Iniguez, K. Otsuki, L.F. Ferreira, A. Araújo, A.C. Vicente, and A.M. Jensen

2008 Chagas disease in Ancient Hunter-Gatherer Population, Brazil. Emerging Infectious Diseases 14:1001-1002.

Martínez, R., C. Ahumada, M.C. Contreras, F. Villarroel, A. Rojas, and H. Schenone

1983 Enfermedad de Chagas en Chile. Sectores rurales. Infestación triatomídea domiciliaria e infección por
Trypanosoma cruzi del vector y mamíferos de la I Región. Boletín Chileno de Parasitología 38:70-72.

Moreno, M.L., D. Gorla, and S. Catalá

2006 Association between antennal phenotype, wing polymorphism and sex in the genus Mepraia (Reduviidae: Triatominae). Infection, Genetics and Evolution 6:228234.

Moreno, A., C.M. Santoro, and C. Latorre

2009 Climate change and human occupation in the northernmost Chilean Altiplano over the last ca. 11500 cal. a BP. Journal of Quaternary Science 24:373-382.

Noireau, F., P. Diosque, and A.M. Jensen

2009 Trypanosoma cruzi: Adaptations to its vectors and itss hosts. Veterinary Research 40:26.

Nei, M.

1972 Genetic distances between populations. The American Naturalist 106:283-291.

Núñez, L., M. Grosjean, and I. Cartajena

2002 Human occupations and climate in the Puna de Atacama, Chile. Science 298:821-824.

Rothhammer, F., V. Standen, L. Núñez, M.J. Allison, and B. Arriaza

1984 Origen y desarrollo de la Tripanosomiasis en el área Centro-Sur Andina. Chungara 12:155-160.

Rothhammer, F., M.J. Allison, L. Núñez, V. Standen, and B. Arriaza

1985 Chagas' Disease in Pre-Columbian South America. American Journal of Physical Anthropology 68:495-498.

Rozas, M., S. De Doncker, X. Coronado, C. Barnabe, A. Tibayrenc, A. Solari, and J.C. Dujardin

2008 Evolutionary history of Trypanosoma cruzi according to antigen genes. Parasitology 135:1-8.

Schofield, C.J.

2000 Trypanosoma cruzi. The vector-parasite paradox. Memórias do Instituto Oswaldo Cruz 95:535-544.

Solari A., A. Wallace, S. Ortiz, J. Venegas, and G. Sánchez

1998 Biological characterization of Trypanosoma cruzi stocks from Chilean insect vectors. Experimental Parasitology 89:312-322.

Spotorno, A.E., L. Córdova, and A. Solari

2008 Differentiation of Trypanosoma cruzi lineage I subgroups through characterization of cytochrome $b$ gene sequences. Infection, Genetics and Evolution 8:898-900.

Tibayrenc, M., and F. Ayala

1987 Forte correlation entre classification isoenzymatique et variabilité de l'ADN kinetoplastique chez Trypanosoma cruzi. Comptes Rendus Acad (Paris) 304:89-92.

Torrico, R.A.

1946 Hallazgo de Eratyrus mucronatus, infestación natural de vinchucas de cerro y Eratyrus sordida en Cochabamba. Anales del Laboratorio Central, Cochabamba 1:19-23.

Villarroel, F., H. Schenone, M. del C. Contreras, A. Rojas, and E. Hernández

1991 Enfermedad de Chagas en el altiplano chileno. Aspectos epidemiológicos, parasitológicos y clínicos. Boletín Chileno de Parasitología 46:61-69.

Venegas, J., S. Ortiz, S. Muñoz, and A. Solari

1997 Molecular karyotype and schizodeme analyses of Trypanosoma cruzi stocks from Chilean triatomines. Parasitology 115:41-46. 
Westenberger, S.J., C. Barnabe, D.A. Campbell, and N. Sturn

2005 Two hybridization events define the population structure of Trypanosoma cruzi. Genetics 171:527-543.

WHO

1991 Control of Chagas Disease. WHO Technical Report Series 811, World Health Organization, Geneve.
Zingales, B., S.G. Andrade, M.R.S. Briones, D.A. Campbell, E. Chari, O. Fernandes, F. Guhl, E. Lages-Silva, A.M. Macedo, C.R. Machado, M.A. Miles, A.J. Romanha, N.R. Sturn, M. Tibayrenc, and A.G. Schijman.

2009 A new consensus for Trypanosoma cruzi intraspecific nomenclature: Second revision meeting recommends TcI to TcVI. Memórias do Instituto Oswaldo Cruz 104:1051-1054. 